\title{
BUDAYA BERKUMPUL PADA UPACARA NGABEN MASA PANDEMI COVID-19 DI BULELENG BALI
}

\author{
Putu Agus Windu Yasa Bukian ${ }^{1}$, Ni Ketut Jayanti ${ }^{2}$ \\ ${ }^{1}$ Program Studi Kebidanan, Sekolah Tinggi Ilmu Kesehatan Buleleng \\ 1jrowindu@gmail.com
}

\begin{abstract}
The implementation of Ngaben is one of the Balinese Hindu traditions for the ceremony of a death. The implementation of Ngaben is a ceremony with a series of many activities and invites a crowd of people. The COVID-19 pandemic period requires people not to carry out gathering activities so that they do not become the cause of the spread of the virus and how to keep ceremonial activities running without reducing meaning. The purpose of this study is to qualitatively identify the culture of gathering during cremation and the solutions offered so that gathering activities do not occur and become the spread of covid-19. This study used a qualitative method through a phenomenological approach, using 4 participants (people who are directly related to religious activities, including the community, community leaders namely head of the ward, 1 participant is a religious leader from the Indonesian Hindu Dharma Association in the Buleleng area). Sampling with nonprobability sampling and using purposive sampling. The results of the study found that there were 3 major themes that were found (1) Ngaben is local wisdom or as a very rigid culture, (2) Ngaben as a form of spreading covid and forming a covid cluster, (3) Changes in Ngaben cultural behavior from conventional to Crematorium. The conclusion is that the community cannot stop cremation activities because it is local wisdom, so to prevent new clusters of covid at the cremation ceremony, the community is required to change their behavior and slowly change the cremation that can be done in the crematorium.
\end{abstract}

\section{Keyword : Gathering, Ngaben, Covid-19, Buleleng}

\begin{abstract}
Abstrak
Pelaksanaan ngaben merupakan salah satu tradisi masyarakat hindu Bali untuk upacara sebuah kematian. Pelaksanaan ngaben merupakan upacara dengan rangkaian kegiatan yang banyak serta mengundang keramaian masyarakat. Masa pandemi covid-19 mengharuskan masyarakat untuk tidak melakukan kegiatan berkumpul agar tidak menjadi penyebab penyebaran virus dan bagaiamana caranya supaya kegiatan upcara tetap berjalan tanpa mengurangi makna. Tujuan dari penelitian ini adalah mengidentifikasi secara kualitatif budaya berkumpul saat ngaben dan solusi yang ditawarkan agar tidak terjadi kegiatan berkumpul dan menjadi penyebaran covid-19. Penelitian ini menggunakan metode kualitatif melalui pendekatan fenomenologi, dengan menggunakan 4 partisipan (masyarakat yang berhubungan langsung dengan kegiatan keagaamaan, meliputi masyarakat, tokoh masyarakat yaitu klian dusun (kepala lingkungan), 1 partisipan tokoh agama dari persatuan hindu dharma Indonesia daerah Buleleng). Pengambilan sampel dengan non probablity sampling dan menggunakan purposive sampling. Hasil penelitian menemukan ada 3 tema besar yang ditemukan (1) Ngaben merupakan kearifan local atau sebagai budaya yang sangat rigid, (2) Ngaben sebagai salah satu bentuk penyebaran covid dan membentuk cluster covid, (3) Perubahan perilaku budaya ngaben dari konvensional ke Krematorium. Kesimpulannya bahwa masyrakat tidak bisa menghentikan
\end{abstract}


kegiatan ngaben karena merupakan kearifan local, sehingga untuk mencegah adanya kluster baru covid pada upacara ngaben, masyarakat dituntut untuk mengubah perilaku dan mengubah secara perlahan ngaben dapat dilakukan di krematorium.

\section{Kata Kunci : Berkumpul, Ngaben, Covid-19, Buleleng}

\section{Pendahuluan}

Bali merupakan salah satu Provinsi yang masih menganut sistem kepercayaan atau tradisi yang kental. Kearifan local yang dimiliki masyarakat Bali masih sangat dalam dan sulit untuk mengubah tradisi dan budaya yang dapat menyesuaikan dengan keadaan saat ini. Keterikatan hindu dengan leluhur mereka sangat kuat dan berkelanjutan. Upacara atau persembahan atau yang sering disebut yadnya pada leluhur adalah dengan melakukan upacara Pitra Yadnya. Pitra yadnya berasal dari kata pitra dan yadnya. Pitra yang artinya leluhur dan yadnya yang artinya korban suci. Sehingga pitra yadnya dalam artian korban suci yang dilaksanakan dan dipersembahkan kepada leluhur (Wikarman, 2002).

Ngaben masih menjadi sebuah tradisi besar umat hindu dan dapat menghabiskan banyak uang untuk menyelesaikan upacara tersebut. Upacara ngaben dahulunya dianggap sebagai upacara yang dapat dilaksanakan oleh orang kaya. Namun saat ini paradigma berganti bahwa upacara ngaben dapat dilaksanakan oleh semua kalangan masyarakat dengan segala kualifikasi dan jenjang masyarakat (Sukraliawan, 2011). Rumitnya pelaksanaan ngaben di Bali sampai saat ini masih terasa. Rigiditas dari pelaksanaan agama atau budaya yang tinggi sehingga menjadi sebuah tradisi yang sangat kental. Pelaksanaan upacara ngaben dengan tradisi yang berdagang serta menyame braya yang wajib dilaksanakan masih dirasakan sampai saat ini di Bali khususnya Buleleng.

Upacara pitra yadnya yang dilakukan oleh masyarakat di Bali merupakan sebuah warisan leluhur. Setiap daerah melaksanakan namun dengan cara yang berbeda. Tetapi tradisi dalam prosesnya hampir sama. Upaya berkumpul dan minum kopi atau meminum minuman yang sama tempatnya dengan orang lain dan Bersama-sama untuk menjadi tetap terjaga masih dilakukan.

Saat ini pandemi masih dirasakan dari berbagai belahan dunia tanpa terkecuali Bali, khususnya Buleleng. Pandemi ini menuntut seluruh masyarakay sadar dan secara berkesinambungan untuk melakukan pencegahan berupa mencuci tangan, menggunakan masker dan menjaga jarak dengan sesama (Sohrabi et al., 2020). Namun jika ini ditermahkan dalam tradisi dan kegiatan ngaben masyarakat di Buleleng, Bali pasti akan menimbulkan upaya pro dan kontra dari berbagai elemen masyarakat. Apalagi ngaben merupakan acara yang sangat padat dan krusial tahap demi tahapnya sehingga sulit untuk melakukan upaya pencegahan dari setiap individu.

Buleleng merupakan salah satu yang masih masuk kedalam zona merah sedangkan tradisi ngaben yang rigid dari upaya bergadang sampai pada berkumpul menyebabkan tradisi ini menjadi sebuah hal yang berbahaya. Dari hal tersebut kami peneliti ingin melakukan penelitian secara mendalam terkait tradisi bergadang dan berkumpul tanpa mematuhi protocol kesehatan saat pelaksanaan ngaben di masa pandemic covid-19 ini. Tujuan penelitian ini adalah mengetahui kedalaman informasi tentang pelaksanaan ngaben masyarakat Bali khususnya Buleleng pada masa covid-19. Kemudian menemukan permasalahan dan memberikan solusi yang dapat ditawarkan untuk mencegah kerumunan banyak ketika pelaksanaan upacara kematian ngaben khususnya.

\section{Metode}

Penelitian ini menggunakan metode kualitatif melalui pendekatan fenomenologi. Penelitian ini mengambil 4 partisipan masyarakat yang berhubungan langsung dengan kegiatan 
keagaamaan, meliputi masyarakat, tokoh masyarakat yaitu klian dusun (kepala lingkungan), 1 partisipan tokoh agama dari Persatuan Hindu Dharma Indonesia Daerah Buleleng. Empat partisipan diambil dari masyarakat yang berhadapan langsung dengan budaya dan tradisi ngaben serta hal terkait keagamaan pitra yadnya. Metode pengambilan sampel pada penelitian ini adalah secara non probablity sampling dengan menggunakan purposive sampling. Partisipan dipilih sesuai dengan kriteria penelitian baik kriteria inklusi dan eksklusi. Partisipan yang dinilai meliputi bagaimana tradisi ngaben dan proses pelaksanaan mulai dari bergadang dan menyebabkan keramaian yang dapat menyebabkan perkumpulan. Bagaimana cara mengatasi situasi tersebut dan bagaimana dilihat dari sisi agama serta sisi budaya. Serta bagaimana dilihat dari sisi Kesehatan dan risiko tertularnya covid-19. Peneliti merekam semua hasil wawancara tersebut dan mencatat seluruh gerak-gerik dan ungkapan yang disampaikan partisipan. Hal-hal tersebut didokumentasikan melalui rekaman dan juga catatan lapangan. Penelitian ini dilakukan di Desa Bungkulan yang merupakan salah satu Desa yang memiliki kekentalan agama dan budaya.

Proses analisis data pada penelitian ini yaitu dimulai dengan mengumpulkan seluruh rekaman, catatan lapangan serta dokumentasi kemudian melakukan transkrip rekaman untuk selanjutnya dilakukan analisa. Setelah melakukan transkrip dari hasil rekaman peneliti kemudian menyusun tema-tema dari hasil rekaman tersebut dan kemudian disusun menjadi sebuah hasil penelitian kualitatif.

\section{Hasil dan Pembahasan}

\section{Ngaben merupakan Kearifan Lokal}

Upacara ngaben merupakan salah satu upacara besar yang dilaksanakan di Bali. Upacara ini besar dikarenakan tradisi ngaben merupakan upacara yang memerlukan waktu yang lama dan banyak. Perilaku ini menjadi sebuah budaya turun temurun dalam pelaksanaannya. Upacara ngaben merupakan upacara Pitra Yadnya atau pengembalian jazad dan raga manusia kepada asalnya yaitu Tuhan.

Secara garis besar Pitra yadnya terdiri dari dua garis besar rangkaian upacara yakni ngaben dan memukur. Tahapan pertama berupa ngaben yaitu pengembalian jazad manuju alam semesta. Pengembalian jazad ini dipandang perlu karena baik manusia maupun alam memiliki unsur yang sama yaitu cair, padat, panas, angin, dan unsur halus (Panca Maha Butha). Kemudian tahap kedua memukur yaitu mengembalikan jazad manusia yang telah bergabung dengan alam menuju alam pitara. Bisa dilakukan 12 hari setelah pengabenan. Tradisi ngaben merupakan tradisi yang memiliki hari terpanjang dalam acara sehingga sangat memungkinkan orang untuk berkumpul dan bergadang. Hal ini merupakan sebuah kearifan lokal dimana ini merupakan kegiatan secara turun temurun yang dilakukan oleh masyarakat hindu. Hasil wawancara dengan partisipan ditemukan sebagai berikut "Tidak ada kearifan local yang salah, kearifan local muncul untuk kebaikan bersama. Sehingga di masa pandemi ini seharusnya bisa menyesuaikan (P1).

Ngaben identik dengan kegiatan yang banyak dan tenaga yang banyak, sehingga memang sangat mungkin adanya kumpul-kumpul sampai bergadang dan menimbulkan keramaian. Hal ini sudah dilakukan sejak turun temurun (P2).

Hasil penelitian ini menemukan bahwa kearifan local menjadi alasan paling utama ngaben masih menimbulkan keramaian, budaya bergadang dan budaya yang membahayakan dan mempercepat penyebaran covid-19. Ngaben dimulai dari jaman pra sejarah yang telah kuat dilakukan bagi perkembangan selanjutnya (Aryanatha, 2019). Seluruh kegiatan agama memang sudah dimulai dari turun temurun dan hal ini tampak dari masa bali kuno, masa Bali majapahit, mas Gelgel, masa Klungkung sampai saat ini. Pengaruh masa Bali majapahit sangat memiliki pengaruh yang besar dalam prosesi upacara ngaben. Dahulu berdasarkan kearifan 
local ngaben dilaksanakan secara sederhana selanjutnya seiring berjalannya waktu maka ngaben pun dibagi menjadi beberapa kriteria alit, madya sampai agung (Aryanatha, 2019).

Secara sejarah atau histori kita melihat gambaran bahwa upacara kematian jenazah rajaraja pada masa Bali Kuno masih melaksanakan sistem pemakaman (Ardana, 2002). Selanjutnya dimulai dengan upacara ngaben beya tanem pada masa Bali Majapahit sampai sekarang. Pemahaman terkait ngaben juga Sebagian besar masyarakat sudah mengetahuinya dengan tujuan utama adalah melakukan pembakaran jenazah. Selain merupakan sebuah kearifan local. Ngaben juga sampai saat ini masih sebagai daya Tarik pariwisata baik secara domestic dan mancanegara.

Upacara ngaben sebagai daya tarik pariwisata tidak hanya dinikmati oleh wisatawan di puri-puri besar Bali melainkan yang bukan dari kalangan puri pun masih menjadi daya tarik sebuah kearifan local yang masih menimbulkan perkumpulan dan keramaian yang tidak bisa dihindari (Puspa \& Saitya, 2018). Sama halnya dengan hasil penelitian terdahulu secara observasi melihat bahwa banyak wisatawan yang tumpah ruah kejalan disaksikan dan diikuti paling sedikit ratusan orang. Wisatawan banyak yang ikut turun ke jalan menyaksikan perjalanan wadah sampai pada setra (Puspa, 2010). Hal inilah yang mengakibatkan berkumpulnya banyak orang tanpa mengindahkan protocol kesehatan yang harus diterapkan.

\section{Membentuk Cluster Covid-19}

Hasil wawancara yang ditemukan terkait dengan pembatasan kegiatan ngaben untuk menghindari cluster baru dari penularan covid-19. Hasil dari beberapa wawancara mendalam ditemukan sebagai berikut. "Seperti kita ketahui, memang covid-19 ini sangat cepat penularannya, terutama varian yang baru terus bertambah, sehingga pembatasan kegiatan acara menjadi sangat penting, tetapi kalau sulinggih yang memuput mau. Kegiatan ngaben dapat dilaksanakan asal pembatasan orang"(P4).

"Memang yang berperan penting disini adalah tokoh masyarakat. Jika tokoh masyarakat tidak tegas maka ngaben akan tidak terkendali keramaiannya" (P2). Pandemi ini merubah banyak tatanan social budaya yang bergeser dan mulai mengalami perubahan. Banyak penyesuaian yang dilakukan terhadap kehidupan social budaya khusunya masyarakat Hindu di Bali. Hal ini yang dapat menimbulkan efek positif dan negative yang bisa diterima ataupun tidak oleh masyarakat luas. Sehingga sangat berpengaruh terhadap pelaksanaan kegiatan keagamaan di Bali (Murdiana, 2021). Kluster baru dimulai dari tidak adanya social dan physical distancing yang dilakukan oleh seluruh masyarakat yang mengadakan upacara keagamaan. Seperti kita sudah ketahui bahwa ada beberapa cara penularan yang dapat dengan cepat terkait dengan peningkatan kluster pada upacara keagamaan adalah (a) Tidak menggunakan masker atau tidak mengindahkan protocol kesehatan yang ketat (b) tidak menjaga jarak (3) dapat berkontak erat dengan orang tanpa gejala maupun dengan yang sudah terkonfirmasi covid-19 (Razi, 2020).

Wabah covid-19 akhirnya membuat beberapa peraturan yang menghambat kegiatan agama di Bali. Tidak lain adalah untuk memutus rantai covid-19 yang takutnya penyebab munculnya kluster baru adalah pada kegiatan upacara agama khusunya ngaben ini. Walaupun hal ini memicu konflik masyarakat tetapi ada beberapa sisi positif yang dapat diambil agar tidak terbentuknya kluster pada upacara keagamaan yaitu (a) dapat mengurangi biaya upacara baik itu ngaben dan upacara agama lainnya, (b) focus pada tata titi upacara atau rangkaian upacara yang harus dilewati. Sehingga moment yadnya yang dilakukan hanya bersama keluarga terdekat dan dapat menjalin keharmonisan dalam keluarga (Murdiana, 2021).

\section{Mengubah Perilaku Budaya Berkumpul Saat Ngaben}

Covid-19 saat ini telah menyebar ke seluruh pelosok negeri dan dunia sehingga bisa disebut sebagai sebuah pandemic. Mengubah perilaku masyarakat dalam kegiatan social 
memiliki risiko yang sangat tinggi mengalami penolakan. Seperti kita ketahui bahwa secara teori perubahan perilaku memiliki tingkatan berbagai macam. Salah satunya adalah teori terkait dengan transtheoretical model dimulai dengan pra contemplation dimana seseorang tidak peduli dalam melakukan aksi terhadap masa depan yang dapat diperkirakan, selanjutnya adalah tahap contemplation dimana dalam tahap ini kemungkinan sudah mengalami perubahan tetapi sering kali tidak terlalu kuat. Banyak yang harus dipertimbangkan dari perubahan perilaku yang akan dilakukan secara berkelanjutan. Tahap selanjutnya adalah persiapan dimana tahap ini secara khusus melakukan beberapa aksi yang signifikan dengan sebelumnya. Tahap selanjutnya adalah action dimana aksi yang dilakukan untuk melakukan perubahan perilaku dan dilakukan dengan sungguh. Terakhir adalah maintenance dimana tahap ini menjadikan sebuah perilaku sebagai sebuah kebiasaan (Velicer, 1998).

Hasil penelitian ini menemukan bahwa partisipan menyebutkan "kalau mengubah perilaku masyarakat tidak mudah apalagi terkait dengan upcara dan upakara. Mereka akan selalu memberikan yang maksimal walaupun mengundang banyak orang. Asalkan jalannya upacara dapat maksimal" (P2).

"Jika Parisada Hindu Dharma Indonesia (PHDI) menghendaki dan mengeluarkan surat edaran khusus untuk pembatasan kegiatan. Saya rasa masyarakat secara tidak langsung pasti akan mengikuti aturan dan menjalankan upacara serta upakara yang diatur oleh PHDI"(P4).

Awig-awig adat atau banjar mempunyai pengaruh yang besar dalam sebuah ritual khususnya ritual kematian. Awig-awig yang tidak tertulis ini yang menyebabkan banyaknya masyarakat berbondong-bondong datang ke upacara kematian untuk melakukan nyame braye (Arjawa, 2016). Perilaku inilah yang mengundang perilaku berkumpul saat kematian ataupun ngaben. Perubahan perilaku sangat mungkin dilakukan tetapi tidak dengan mudah diterapkan kepada masyarakat.

Mucullah fenomena ngaben di Krematorium selain untuk mengurangi atau membatasi orang. Pelaksanaan pengabenan atau upacara kematian juga semakin dipermudah dan tidak mengundang banyak orang. Legitimasi social merupakan sebuah persyaratan penting pembaharuan perilaku masyarakat dalam melakukan upacara pengabenan di kremetorium.

Dalam ngaben crematorium perlu adanya tokoh yang memuput acara dalam ngaben yaitu seorang sulinggih atau pendeta sehingga akan membentuk legitimasi masyrakat (Arjawa, 2016). Sehingga dari hal tersebut hanya terdapat perbedaan acara ngaben di krematorium dan konvensional dilihat pada penggunaan kuburan dan penggunaan pemimpin upacara dalam kegiatan ngaben.

Secara rasionalisasi upacara ngaben krematorium tidak berbeda jauh dengan pelaksanaan ngaben secara konvensional. Sehingga sangat memungkinkan menggunakan krematorium sebagai pengganti ngaben konvensional di masa pandemi ini. Dalam sistem kehidupan adat di Bali, sebagian besar upacara akan dilakukan bergotong-royong. Mead menyebutkan bahwa hampir dalam setiap aspek, masyarakat Hindu Bali bekerja bersamasama, meskipun individu yang bersangkutan tidak terampil dalam suatu pekerjaan, tetapi itu akan tetap dilakukan (Arjawa, 2016). Sehingga jika sudah terjalin perubahan perlaku secara perlahan masyarakat terkait pelaksanaan ngaben di kreamtorium niscaya kedepan sebuah upacara keagamaan bukan lagi menjadi kluster penyebaran covid-19 dan pelaksanaan upacara serta upakara dapat sesuai dengan yang seharusnya tanpa mengurangi arti atau makna pelaksanaan tersebut.

\section{Kesimpulan}

Terdapat 3 tema besar yang ditemukan dari penelitian ini (1) Ngaben merupakan sebuah kearifan local dan budaya yang dijalankan secara turun temurun sejak jaman dahulu, kerajaan majapahit, klungkung sampai saat ini. (2) Ngaben dikatakan sebagai salah satu kluster penyebaran covid-19 sehingga sangat penting untuk membatasi kegiatan ngaben pada 
masyarakat di masa pandemi. (3) Perubahan perilaku masyarakat terkait ngaben menjadi satu hal penting. Dahulu ngaben dilakukan secara konvensional dengan jadwal kegiatan dan pelaksanaan yang rigid namun saat ini diupayakan mengalami perubahan paradigma menggunakan upacara ngaben secara krematorium untuk membatasi orang dan tidak mengurangi makna dari pelaksanaan ngaben.

\section{Daftar Pustaka}

Ardana, S. (2002). Sejarah Perkembangan Agama Hindu di Indonesia. Paramita.

Arjawa, S. (2016). Ngaben di Krematorium (Fenomena Perubahan Sosial di Bali). Pustaka Ekspresi.

Aryanatha, I. N. (2019). Ritual Agama Hindu dalam Membudayakan Nilai-Nilai Kearifan Lokal. Widya Duta: Jurnal Ilmiah Ilmu Agama Dan Ilmu Sosial Budaya, 13(2), 1. https://doi.org/10.25078/wd.v13i2.673

Murdiana, I. K. A. (2021). Dampak Virus Corona Terhadap Kehidupan Sosial Budaya Masyarakat Hindu Bali (Perspektif Pendidikan Agama Hindu). 1(1), 32-43.

Puspa, I. A. T. (2010). Estetika Hindu dalam Upacara Pitra Yadnya di Desa Pakraman Beraban Tabanan.

Puspa, I. A. T., \& Saitya, I. B. S. (2018). Ngaben sebagai Daya Tarik Pariwisata.

Razi, H. . (2020). Bunga Rampai Covid-19: Buku Kesehatan Mandiri Untuk Sahabat \#Dirumahaja. Pd Prokami Kota Depok.

Sohrabi, C., Alsafi, Z., O’Neill, N., Khan, M., Kerwan, A., Al-Jabir, A., Iosifidis, C., \& Agha, R. (2020). World Health Organization declares global emergency: A review of the 2019 novel coronavirus (COVID-19). International Journal of Surgery, 76(February), 71-76. https://doi.org/10.1016/j.ijsu.2020.02.034

Sukraliawan, I. (2011). Reinterpretasi Makna Ngaben Masal pada Masyarakat Desa Sudaji: Suatu Kajian Budaya. Widyatech Jurnal Sains Dan Teknologi, 11(1), 120-133.

Velicer, W. . (1998). Detailed Overview of the Transtheoretical Model. Addictive Behaviour, 38(20), 216-233.

Wikarman, I. (2002). Ngaben (Upacara dari Tingkat Sederhana sampai Utama). Paramita. 